NIKICA GILIĆ

Faculty of Humanities and Social Sciences University of Zagreb

\title{
Localised dystopia in Croatian and Serbian cinema
}

\begin{abstract}
Gilić Nikica, Localised dystopia in Croatian and Serbian cinema. „Images” vol. XXIII, no. 32. Poznań 2018. Adam Mickiewicz University Press. Pp. 39-47. ISSN 1731-450X. DOI 10.14746/i.2018.32.04.

Genre production is often easily localised in various cultures, but localisations of science fiction seem particularly interesting, due to the technological sources of the genre imagery and typical narrative structures. Localisation to a less technologically-oriented society, such as post-yugoslav Croatia and Serbia, are a very good example, since in such films as The Show Must Go On (by Nevio Marasović) and Technotise - Edit \& I (by Aleksa Gajić and Nebojša Andrić) allegorical science fiction deals directly with local problems and narrations, such as Croatiass obsession with modernisation and Western-European identity (in Marasovićs film) and Serbia’s traumatic relation with Slobodan Miloševićs regime and national pride (in Gajićs and Andrićs animated feature film). The experimental concept of Unknown Energies, Unidentified Feelings (by Dalibor Barić and Tomislav Babić) provides another model of dealing with genre structures in a local context, since it directly develops the early-1970s model of connecting experimental cinema with the technological obsessions of the era (important for entire Yugoslavia through the GEFF festival) into a contemporary experimental animated dystopia.
\end{abstract}

Keywords: The Show Must Go On, Technotise - Edit \& I, Unknown Energies, Unidentified Feelings, dystopian cinema, post-yugoslav cinema

Genre production is often and relatively easily localised within various regions and cultures, and post-yugoslav cultures are no exception to this rule. Localisations of science fiction might be of particular interest in this respect, due to the technological components of the genre, its prototypical imagery and its typical narrative settings, situations and developments. Localisations of science fiction in technologically less developed (or even less technologically oriented) societies, such as post-yugoslav Croatia and Serbia (the strongest film production centres in this cultural space), present SF-oriented artists with interesting challenges.

If a film placed in these societies is very technological in its iconography or social structuring, it might seem unconvincing (trivial), or perhaps more conspicuously allegorical than is usually the case with works of a SF nature.[1] Yet, the dystopian models often found within science fiction can be of even greater interest here; not inherently or at least heavily centred around technological iconography and imagery, dystopia can present local filmmakers or writers (or comics authors) with various (not only technological) models for depicting localised

[1] In the Zagreb school of animated film (e. g. Ersatz [Surogat, Dušan Vukotić, 1961]) the society depicted hardly corresponded to developments in Yugoslavia at the time. Like many other films from the school,
Images vol. XXIII/no. 32

Poznań 2018

ISSN 1731-450X 
negative visions of society. Of course, some dystopian SF models are technological to the extreme (cyberpunk with its later variations and mutations), [2] but that is of lesser importance to this discussion.

Some models for presenting localised dystopias can be found in films and animated films such as The Show Must Go On (2010), directed by Nevio Marasović),[3] Technotise: Edith \& I (Technotise: Edit i ja, 2009), directed by Aleksa Gajić and Nebojša Andrić, and Unknown Energies, Unidentified Feelings (Nepoznate energije, neidentificirani osjećaji, 2015), directed by Dalibor Barić and Tomislav Babić. The first of these is a live-action dystopian feature, the second is feature-length animation, based on the ideas from a SF comic, [4] and the third is an example of experimental animation that relies heavily on the conventions and traditions of avant-garde, experimental filmmaking.

These works are a very good testimony of how localized dystopian structures can refer directly to local problems and cultural narratives, such as Croatia's contemporary obsession with modernisation and Western-European identity in Marasovićs film, or Serbia's traumatic relation with recent history - Slobodan Miloševićs regime - and national pride in a very interesting episode of Gajić's and Andrićs animated work. In the third example, the Croatian and Yugoslav era of modernisation and culturally radical exploration of cinema and society is evoked on the borders of the SF genre, animation and experimentalism.

Classifying dystopia as part of the science fiction genre would certainly raise some eyebrows given the long tradition and many forms of dystopia (discussed, among others, in relation to the phenomenon of young adult literature), [5] but there is no ambition to strictly define the relationship between dystopia and science fiction in this discussion. A great number of dystopian films and novels, however, easily qualify as science fiction, and the science fiction interpretative community is happy to embrace dystopian books or films (as seen in a very interesting encyclopaedia of SF printed in Serbia at the very end of the Yugoslav era).[6] It thus suffices to say that the Croatian low-budget SF film The Show Must Go On has strong dystopian element in its depiction of society, with the cynical media offering the reality television show Housed as the last refuge for a population heading for mutually assured destruction. In this film the Croatian government works hand-in-hand with the media in making citizens docile and accepting of certain nuclear annihilation, [7] caused by an inevitable clash between East and West.

[2] E.g. the short story Bloudhound and the rats (M. Benini, Krvosljednik i štakori, in: Ad astra. Antologija hrvatske znanstvenofantastične novele, eds. T. Šakić, A. Žiljak, Zagreb 2006, pp. 573-582).

[3] An alternative title of Marasović's film, 101 Days, on the internet (cf. <www.imdb.com $>$ ), although it has never gained traction in the distribution of the film. Also, the definite article at the beginning of the film's title is sometimes omitted.
[4] A. Gajić, D. Grkinić, Technotise, Beograd 2009, 2nd edition.

[5] A.H. Sturgis, Not your parent's dystopia, "Reason" 2014, no 5 (46), pp. 46-51.

[6] Z. Živković, Enciklopedija naučne fantastike 1-2, Beograd 1990.

[7] J. Pavičić, Film “The Show Must Go On”: Dobra distopija s neuvjerljivim glavnim junacima, "Jutarnji list" 2011, no. 4649, <http://www.jutarnji.hr/kultura/ 
The potentially powerful effect of Marasovićs vision is confirmed by the film critic's Oktavijan Award, which was quite surprising for this small, albeit ambitious directorial debut, but The Show Must Go On has won other awards as well, including the jury-awarded Zlatna Arena (Golden Arena) for the best script in a national competition at the Pula Film Festival.[8] Since character depth or development are hardly the most significant features of Marasovićs first feature film (in terms of characters, the script is rather undeveloped), the jury was probably swayed by its futurist and dystopian vision, easily deemed relevant for Croatia's contemporary obsession with "transition" and the path to the west (NATO and EU being key ingredients in this western-bound narrative).

Not unusual for science fiction or for dystopia (and for their zone of intersection), The Show Must Go On also plays gently with the trope of a reversed world, with easily discernible local colouring. International viewers with less than detailed knowledge of recent regional history might find nothing unusual with the idea that heroes of Marasovićs film plan the move from Zagreb (in Croatia) to Sarajevo (in Bosnia and Herzegovina), in order to avoid the ravages of an imminent World War III. Most of the regional viewers, however, can have no trouble understanding the bitter irony of this idea and the way in which it comments on the unquestionable values of Croatian society. Many may even feel unease with such a reversal of relatively recent historical migrations: in the 1990s the citizens of Sarajevo (and of Bosnia and Herzegovina in general) were often fleeing the most terrible warfare in that country, finding refuge in Zagreb and other parts of Croatia. For local audiences, this reversal of Zagreb's and Sarajevo's fortunes is quite easily comprehensible in its many connotations (admittedly, this can also be connected to the trope of the wheel of fortune, also well documented in literary history and in cinema).[9] However, the level of destruction presented at the end of Marasovićs film suggest that even Sarajevo would not have been a safe haven after all, although it was neutral in the war between the West and the East.

This sort of allegorical reversal is neither new nor exclusive to science fiction (although literary texts from past centuries have occasionally been classified as science fiction, most famously for Yugoslavia in Darko Suvin's early attempt to canonise the genre).[10] From Jonathan

film-i-tv/film-the-show-must-go-on-dobra-distopija-s-neuvjerljivim-glavnim-junacima/2044260/> [accessed on: 15.10.2016].

[8] <http://arhiv.pulafilmfestival.hr/57/hr/indexd37a. html?p=list\&group=1> [accessed on: 10.10.2016]. [9] In John Landis' film Trading Places (1983), or in Ivan Gundulićs 17 th century verses from Tears of the Prodigal Son (Suze sina razmetnoga): "Kolo od sreće uokoli vrteći se ne pristaje: tko bi gori, eto je doli, a tko doli gori ustaje" ("The wheel of fortune keeps going around: those who were on the top end up way down, and those who were down will rise to the top"), available at <http://www.gssjd.hr/wp-content/uploads/2010/11/gundulic_suzesinarazmetnoga.pdf $>$. [10] D. Suvin, Od Lukijana do lunjika. Povijesni pregled $i$ antologija naučnofantastičke literature, Zagreb 1965. In local literary traditions the medieval poem The world is ending (Svit se konča) is one of the most famous and oldest sources for the idea of the world turned upside down (available at: <https:// 
Swift's satire in Gulliver's Travels to Desmond Nakano's film White Man's Burden (1995), the title of which ironically references the racist trope of whites being the benevolent master/guides of lesser races (or, to be more precise, Rudyard Kipling's poem written in support of the US invasion of the Philippines).[11] However, in more or less mainstream SF the idea of a reversed society (and world) is often found as well, from Pierre Boulle's novel La Planète des Singes, [12] and its famous, relatively faithful film adaptation, Franklin J. Schaffner's film Planet of the Apes (1968), where apes cage human animals, to Star Trek's famous episode Mirror, Mirror, in which the heroes travel to a violent alternate reality visited in later instalments of the Star Trek franchise as well. Or, for that matter, to the entire concept of another television series, Sliders, where many episodes about travellers through parallel universes depict reversed worlds or societies. In one world/episode, for instance, The Soviets rule the USA, while in another the singer Mel Tormé plays the role of a legendary singer (basically - "himself"), only to turn out to be a country and western (instead of jazz) singer in this reversed world.

Not limiting itself to the SF model (or sub-genre) of parallel universes, the idea of reverse society perseveres in fiction in a futurist form, similar in some cases to Marasović's, for instance, in John Milius' film Red Dawn (1984),[13] or Asja Bakić's short story Way to the West (Put na Zapad) from her book of short stories Mars, where a war-ravaged and starving Europe loses its last inhabitants as refugees to a more fortunate Africa.[14]

In Serbian animation Technotise: Edith \& I, based rather loosely on Aleksa Gajićs comic (for the most part it can be viewed as a sequel to the comic), a typical mix of dehumanising technology, corporate greed and manipulation, and action sequences. One might say that the highly technological futurist society depicted in Technotise can itself serve as a reversal not only of the real characteristics of post-Yugoslav Serbia (or the region in general), but also of the stereotypical manner in which Serbian society is depicted in cinema and television, with a strong tendency towards the imagery of it as naturalist, shabby, dirty and poor - from Živojin Pavlovićs or Aleksandar Petrovićs classical films, through Slobodan Šijan's magnificent and popular comedies, to the more recent productions of different genres, such as TV series The Storks Will Return (Vratiće se rode, Goran Gajić, 2007-2008) or the film

hr.wikisource.org/wiki/Svit_se_kon\%C4\%8Da>). In addition to that, Suvin's famous anthology of science fiction tradition quotes from the prologue of Marin Držićs reneissance comedy Dundo Maroje (ibidem; pp. 8o-87)

[11] The film shows USA in which African Americans completely dominate the society. For Kipling see: $<$ http:/historievg2.cappelendamm.no/aim/cappelen$\operatorname{prod} / 2 / 78 / 40 /$ storage/file.application.pdf $>$.

[12] Due to the limited marketing potential of SF in Yugoslavia, the title was translated as I fell in love with a wild woman (P. Boulle, Zavolio sam divlju ženu, trans. A. Curčić, Zagreb 1965).

[13] Red Dawn (1984), due to its political nature, can avoid being marketed and percieved as a SF film. The eponimous remake directed by Dan Bradley in 2012, with North Korean invasion, seems less futuristic and more ridiculous.

[14] Bakić’s book is reviewed in I. Šunjić, Pripovjedni modeli u zbirci priča "Mars" Asje Bakić, "Ubiq" 2016, no. 18 , pp. 173-185. 
The Life and Death of a Porno Gang (Život i smrt porno bande, 2009) directed by Mladen Đorđević.

In order to ensure that the viewer of Technotise definitively recognizes this high-tech society as Serbia in the future, localizations are relatively numerous, from still recognisable geographical locations and cultural codes, to the local Belgrade vernacular being used even by the Chinese-Serbian character Jovan $\mathrm{Vu}(\mathrm{Wu})$. In addition, there are clear quotations from various layers of Serbian culture, such as the narratively unmotivated inclusion of a stereotypical Serbian peasant character, based on a supporting character (and quoting his line) from Slobodan Šijan's widely popular film Who's Singing Over There? (Ko to tamo peva, 1980). In the Croatian short SF comedy Zovko Teleport Agency (Teleport Zovko, Predrag Ličina, 2013), a comical localization of a similar kind is crucial to the ending of the story: a botched teleportation from the unattractively depicted future causes the apparition of the Virgin Mary in Međugorje in the 1980s (actually - a nude women teleported from the future).[15]

There are, however, strong signs of a different approach to localization in Technotise when compared to Marasovićs film. In some aspects (plot, general technological imagery) Technotise is a rather typical futurist SF story, influenced by the graphic novels of Moebius and Japanese Manga comics and Anime films, only partly localised to Serbian culture and history; however, it also includes a very powerful, albeit short flashback to the political chaos of overthrowing Slobodan Milošević, one of the focal points of recent Serbian history. Some may consider this flashback to Miloševićs downfall to be a mere distraction, [16] because it can hardly be seen as narratively functional or visually coherent with the rest of the story. But, you can hardly treat such a heavy topic in Serbia or post-Yugoslav region and limit it to its narrative length, as Serbian critic Dimitrije Vojnov also seems to suggest.[17] The animal that comes out from Milošević's head is very disturbing and one cannot but wonder where it has gone after leaving Miloševićs body.

In addition, the fact that the film actually ascribes an alien (non-human) or even supernatural quality to political power/evil (Slobodan Milošević) is not out of place when discussing dystopian leaders, [18] but it seems to connect Technotise to the most politically charged tendencies in science fiction, or even horror, much more than its narrative structure would suggest. Films such as John Sayles' The Brother From Another Planet (1984), Krsto Papićs The Redeemer (Izbavitelj, 1976) or Jean-Luc Godard's Week End (Week-end, 1967),

[15] Needless to say, such satyrical treatment of a popular Roman Catholic pilgrimage site in Bosnia Herzegovina is heavily political in Croatian society. [16] I. Subakov, TEHNOTISE - EDIT I JA (2009) KRITIKA, "Novi kadrovi” 2014, <http://novikadrovi. blogspot.hr/2014/o8/tehnotise-edit-i-ja-2009-kritika. html> [accessed on: 15.10.2016].
[17] D. Vojnov, "Edit i ja", "Doba nevinosti blog" 2009, <http://dobanevinosti.blogspot.com/2009/10/ edit-i-ja.html [accessed on: 22.10.2016].

[18] As rightly stated by Slaven Škapul (pp. 228-229):

S. Škapul, Imaginarij distopijskog filma (predstavljanje novog filmskog žanra), "Ubiq" 2014, no. 15, pp. 207-249. 
otherwise completely different live action motion pictures, actually share this feature with Gajić's work. Its monstrous depiction of the Serbian president also connects Technotise with a horror tradition stemming to a significant extent from the prose of H.P. Lovecraft, and flourishing in horror/SF hybrids quite popular in cinema since at least the 1970s. If Marasovićs The Show Must Go On attacks contemporary Croatian society, there is a good argument to be made that Technotise uses dystopian elements to suggest something deeper about Serbian history. It would, however, be fair to state that the level to which Technotise is a dystopian piece of work partly depends on the viewers cultural predilection (or even age): young viewers might find the society based on technological inventions and corporate greed as something normal instead of something negative, while concentrating on the more positive aspects of the heroes' lives; the potential for the technological disruption of humanity (convincingly depicted through the intelligence growing within Edith's body) nevertheless seems to be a strong signal of a negative take on technological society.

Narrative digression with Miloševićs otherness (in my opinion, one of the key scenes in Technotise) makes this generally populist piece of animated science fiction into a very politicized and political film, partly commenting on similar topics as those of the infamous The Serbian Film (Srpski film, Srđan Spasojević, 2010), but also comparable to Sreten Ugričić's experimental dystopian novel To the Unknown Hero (Neznanom junaku, 2010), where mixed Latin and Cyrillic letters are used to accentuate the negative in Serbian society. There are, of course, localised and politically charged dystopian works elsewhere, such as Neill Blomkamp's District 9, a film that is, among other things, an allegory of South African apartheid, but also of intra-racial relations within that country. But, among other Yugoslav and post-Yugoslav localizations, one could name the dystopian novel Ut's Diary (Utov dnevnik) by Branko Belan from the Yugoslav era or, more recently, Battlefield Istria (Bojno polje Istra) by Danilo Brozović, [19] and The God's State 2053 (Država Božja 2053) [20] by Ivo Brešan, both by Croatian writers, or The Ghetto (Geto, 2006) by Veselin Gatalo from Bosnia Herzegovina. It would be a grave mistake, however, to forget the Serbian dystopian tradition from the Yugoslav era as well, with writers such as Dragan Orlović (1984), Zvonimir Kostić (1986) and Ivan Ivanji (1980), who published their respective dystopias Talason, Netherworlds (Donji svetovi) and The World Remains in the End (Na kraju ostaje reč) in the influential Kentaur edition (publication of Belgrade publisher Prosveta),[21] widely read throughout Yugoslavia.

[19] The title mocks L. Ron Hubbard's notorious novel Battlefield Earth.

[20] Clear allusion to Croatian translation of the title of Augustine's City of God (De civitate dei).
[21] Belan's Ut's diary was also published in this book series. Orlović's novel is touted as a "localisation" of Orwell's landmark work 1984 on the cover of the book (this unattributed praise is, presumably, written by somebody from the publishing firm). 
Finally, we can also speak of a third, least populist manner in which general dystopian features are localized by Dalibor Barić and Tomislav Babić in Unknown Energies, Unidentified Feelings (Nepoznate energije, neidentificirani osjećaji). [22] Due to its artistic ambitions, this is hardly a typical genre production, but it seems relevant to a discussion of the localization of dystopia. Made as part of a project commemorating the anniversary of the GEFF experimental cinema festival, [23] held in Zagreb, but also important for all Yugoslav experimental and alternative cinema of the era,[24] this works takes the title of an edition of the festival that was never realised due to the complex social and political environment of the first half of 1970s. Screened in various contexts (for instance, as part of the official competition at Zagreb's Animafest, the world festival of animated film and receiving several awards, such as the award for best writing at the Days of Croatian Cinema (Dani hrvatskog filma), a festival for all types of film except feature-length fiction films, [25] Unknown Energies is a densely structured, highly experimental work, similar to several of Barićs shorter films with a similar experimental approach to various genre and media elements, such as Ghost Porn in Ectoplasm, but How?! (2010), New hippie future (Nova hipi budućnost, 2011) or Amnesiac on a beach (Amnezijak na plaži, 2013).

Unknown Energies only suggests real narration, using genre and animation to suggest the possibilities for forming a coherent fictional word or a discernable story. The sketchily formed characters in the film discuss various topics, often pseudo-scientific and semi-futuristic, in accordance with the poetics of the era, when a technologically oriented edition of GEFF was supposed to be held. The fact that Tomislav Babić, an expert in sound in general, and sound in cinema in particular, gets the co-authorial credit together with Barić is also of interest here: Unknown Energies is actually a film about technology and its function in transforming society, in accordance with the poetics of GEFF, and sound technology is essential for this work.

A highly elitist piece of art, Barić and Babićs film proves the power of genre as a model of cultural communication: for fans of cinema genre is often one of the legitimate models of expression, available to be freely mixed with any other manner of creation. Naturally, in this case, it is a consequence of an older localisation, experimentalist fixation on

[22] Naturally, the dystopian orientation of Marasović's and Gajićs work is logical if we take into account the fact that the cinema audiences are nowadays very young and often interested in SF and similar genre. [23] Ž. Kipke, Nepoznate energije. 24. Dani hrvatskog filma, Zagreb, 23. - 26. travnja 2015, "Filmovi. hr" 2015, <http://www.filmovi.hr/index.php?p=article\&id=2209> [accessed on: 15.10.2016].

[24] Ž. Luketić, Genre Film Festival (GEFF) 1963. 1969.: Propuštena obljetnica, "Oris" 2014, no. 86, pp. 212-219, <http://www.oris.hr/hr/casopis/clanak/ [50]\%3 Ci\%3Egenre-film-festival\% ${ }_{3} \mathrm{C} \_$i $\% 3$ E-(gef- f)-1963---1969-propustena-obljetnica,740.html> [accessed on: 15.10.2016] For the festival bulletins and other printed materials see: $<$ http://www.avantgarde-museum.com/en/museum/collection/authorsGEFF pe 4528/\#overlay>. Arin Medosch describes the movements in visual arts of the era, placing GEFF in that context: A. Medosch, New Tendencies: Art at the Threshold of the Information Revolution (1961 -1978), Cambridge-London 2016, p. 100.

[25] Cf. D. Štimac, Otmice, roboti i simulacije - znanstvena fantastika i 24. Dani hrvatskog filma, "Hrvatski filmski ljetopis” 2015, no. 82-83 (25), pp. 125-128. 
modernisation and technology from the era of actual GEFF, when all manners of technological experiments and innovations were inseparable from the idea of expanding the art, but also consciousness. Just like GEFF, this film equates aesthetic and technological explorations, charging them with the task of changing society and humanity itself (with consequences that can be regarded as both utopian and dystopian). "The Second Thesis of GEFF",[26] a part of the festival's manifesto, states that research becomes an "existential human topic", completely changing human behaviour and marking the creation of a "free-secular man" ("slobodno-profani čovjek") who builds and destroys his poetical and practical "theoretical worlds". [27]

The three examples discussed above show the richness of the methods in which dystopia or science fiction can be localised in cinema, and the fact that none of these works was hugely popular with local audiences is also of interest. For Barić and Babić's work to become a hit would be inconceivable, but the first two works are bona fide dystopian SF narrations, a model with at least theoretical populist appeal. However, the fact that these are actually elitist works, not well-known outside of cinema or comics connoisseur circles, might give them an additional aura of respectability with cultural critics, who are still, after all, subject to the twists and turns in academic fashions, and still sometimes sceptical of things populist and/or popular.

B I B L I O G R A P H Y

Bakić A., Mars, Zagreb 2015

Belan B., Utov dnevnik, Beograd 1982

Belc P., Mihovil Pansini i antifilm. Teorijski i povijesni aspekti, "Hrvatski filmski ljetopis" 2016, no. 22 (85), pp. 5-33

Benini M., Krvosljednik i štakori, in: Ad astra. Antologija hrvatske znanstvenofantastične novele, eds. T. Šakić, A. Žiljak, Zagreb 2006, pp. 573-582

Boulle P., Zavolio sam divlju ženu, trans. A. Curčić, Zagreb 1965

Brčić T., Fenomen i kultura kinoklubova šezdesetih godina $i$ utjecaj novih tendencija na festival GEFF, "Zapis. Bilten hrvatskog filmskog saveza” 2008, no. 62 , <http://www.hfs.hr/nakladnistvo_zapis_detail.aspx?sif_clanci=32445\#. WBZXwiSplhY> [accessed on: 28.10.2016]

Brešan I., Država božja 2053, Zagreb 2003

Brozović D., Bojno polje Istra, Zagreb, Sarajevo 2007

Gajić A., Grkinić D., Technotise, Beograd 2009, 2nd edition

[26] T. Brčić, Fenomen i kultura kinoklubova šezdesetih godina i utjecaj novih tendencija na festival GEFF, "Zapis" 2008, no. 62, <http://www.hfs.hr/nakladnistvo_zapis_detail.aspx?sif_clanci=32445\#.WBZXwiSplhY> [accessed on: 28.10.2016].

[27] "Istraživanje je, kako ga suvremena svijest doživljava, novovjekovni fenomen. Nastao je otkako su se teološki, filozofski, umjetnički, znanstveni i politički svjetovi iskazali kao 'provizorni'. Nestale su trajne sigurnosti, i čovjek je postao - 'avantura': Prezire svećenike, ubija kraljeve, ruga se autoritetima: imenuje se slobodno-profanim čovjekom, koji istražujući unutarnji i vanjski stvaralački radijus izgrađuje i razgrađuje svoje poetsko-praktičko-teoretske svjetove. Istraživanje prestaje biti znanstveno-metodološka metoda. Ono je mjera, sve više isključiva, kojom se mjeri ljudski dignitet pojedinca, grupe, naroda. Ono postaje egzistencijalna tema čovjeka." On GEFF see also Knjiga GEFF-a 1963, ed. M. Pansini, Zagreb 1967. 
Gatalo V., Geto, Zagreb 2006

Halper Th., Muzzio D., Hobbes in the city: urban dystopias in American movies, "Journal of American Culture" 2007, no 4 (30), pp. 379-390. doi: 10.1111/j.1542$-734 X .2007 .00615 . \mathrm{x}$

Ivanji I., Na kraju ostaje reč, Beograd 1980

Kipke Ž., Nepoznate energije. 24. Dani hrvatskog filma, Zagreb, 23. - 26. travnja 2015, "Filmovi.hr" 2015, <http://www.filmovi.hr/index.php?p=article\&id=2209> [accessed on: 15.10. 2016]

Knjiga GEFF-a 1963, ed. M. Pansini, Zagreb 1967

Kostić Z., Donji svetovi, Beograd 1986

Luketić Ž., Genre Film Festival (GEFF) 1963. - 1969.: Propuštena obljetnica, “Oris" 2014, no. 86, pp. 212-219, <http://www.oris.hr/hr/casopis/clanak/ [50]\%3Ci\%3Egenre-film-festival\%3C_i\%3E-(geff)-1963---1969-propustenaobljetnica,740.html $>$ [accessed on: 15.10.2016]

Medosch A., New Tendencies: Art at the Threshold of the Information Revolution (1961-1978), Cambridge, London 2016

Mileta S., Znanstvenofantastično naslijeđe Darka Suvina, "Književna republika" 2011, no. 10 (12), pp. 109-142

Mirrlees T., Hollywood's Uncritical Dystopias, “Cineaction” 2015, no. 95, pp. 4-15

Orlović D., Talason, Beograd 1984

Pavičić J., Film “The Show Must Go On”: Dobra distopija s neuvjerljivim glavnim junacima, "Jutarnji list" 2011, no. 4649, <http://www.jutarnji.hr/kultura/film-i-tv/film-the-show-must-go-on-dobra-distopija-s-neuvjerljivim-glavnim-junacima/2044260/> [accessed on: 15.10.2016]

Škapul S., Imaginarij distopijskog filma (predstavljanje novog filmskog žanra), "Ubiq. Časopis za znanstvenu fantastiku" 2014, no. 15, pp. 207-249

Štimac D., Otmice, roboti i simulacije - znanstvena fantastika i 24. Dani hrvatskog filma, "Hrvatski filmski ljetopis" 2015, no. 82-83 (25), pp. 125-128

Sturgis A.H., Not your parent's dystopia, "Reason” 2014, no. 5 (46), pp. 46-51

Subakov I., TEHNOTISE - EDIT I JA (2009) - KRITIKA, "Novi kadrovi” 2014, $<$ http://novikadrovi.blogspot.hr/2014/08/tehnotise-edit-i-ja-2009-kritika. html> [accessed on: 15.10.2016]

Šunjić I., Pripovjedni modeli u zbirci priča "Mars" Asje Bakić, "Ubiq. Časopis za znanstvenu fantastiku” 2016, no. 18, pp. 173-185

Suvin D., Od Lukijana do lunjika. Povijesni pregled i antologija naučnofantastičke literature, Zagreb 1965

Ugričić S., Neznanom junaku, Beograd 2010

Ukronije. Zbirka spekulativne fikcije, eds. I. Delač, T. Jambrišak, D. Vrban, Zagreb 2014

Vojnov D., Edit i ja, "Doba nevinosti blog” 2009, <http://dobanevinosti.blogspot. com/2009/10/edit-i-ja.html> [acessed on: 22.10.2016]

Živković Z., Enciklopedija naučne fantastike 1-2, Beograd 1990

Živković Z., Ogledi o naučnoj fantastici, Beograd 1995 